\title{
FGFR3 Gene
}

National Cancer Institute

\section{Source}

National Cancer Institute. FGFR3 Gene. NCI Thesaurus. Code C24393.

This gene plays a role in bone development and maintenance and mutations in the gene are associated with craniosynostosis and several types of skeletal dysplasia. 